\title{
Studies of the Possibilities to use Ozone for the Grain Storage
}

\author{
Adolfs Rucins \\ Latvia University of Life Sciences \\ and Technologies, \\ Ulbroka Research center \\ Ulbroka, Latvia \\ adolfs.rucins@llu.lv \\ Alberts Kristins \\ University of Latvia, \\ Institute of Solid State Physics \\ Riga, Latvia \\ kristin@latnet.lv
}

\author{
Evita Straumite \\ Latvia University of Life Sciences \\ and Technologies, \\ Faculty of Food Technology \\ Jelgava, Latvia \\ evita.straumite@llu.lv
}

\author{
Dainis Viesturs \\ Latvia University of Life Sciences \\ and Technologies, \\ Ulbroka Research center \\ Ulbroka, Latvia \\ viesturs_uzc@apollo.lv
}

\begin{abstract}
In this study was impact of ozone treatment efficiency of wheat quality (physical-chemical and microbiological parameters, chemical composition and germination rate) during storage analysed. Ozone is a powerful oxidizer, used in processing the agricultural products, including inactivation of pathogens and microorganisms.

Investigations in the grain storage by using ozone were performed under farm conditions during two grain storage stages. The first stage - August 2019 - February 2020 and the second stage August 2020 - January 2021. In both stages after harvesting winter wheat yield was $6 \mathrm{t} \mathrm{ha}^{-1}$. Winter wheat was ventilated and then stored for about five months in two identical $20 \mathrm{~m}^{3}$ tanks, with an initial grain layer height of $5.1 \mathrm{~m}$ and moisture content the first stage of about $14 \%$ and the second stage of about $11 \%$ and initial grain mass 17.4 t.
\end{abstract}

At the beginning of the storage period the grain in both tanks was ventilated for 8 hours - in one grain storage tank with the outdoor air, in the other with an ozone supply of $28 \mathbf{~ m g}$ $\left(\mathrm{m}^{3}\right)^{-1}$ in the ventilation air. The grain ventilation and storage process was monitored with a specially designed sensor system; the additional parameters of the process (the grain moisture content, temperature, the ozone concentration) were periodically controlled with hand tools. There were analysed changes of the grain parameters during the storage periods in the ozone-supplied tank and in the tank without ozone treatment.

The microbiological contamination during storage did not exceed the allowed level; however it was lower in the ozone treated wheat grain than in the ozone untreated grain. The ozone treatment did not affect the grain quality parameters.
The grain germination rate for 3 and 5 days of the ozone treated grain was about $20 \%$ higher than that of the untreated grain. During storage, microbiological contamination did not exceed the permissible level, but ozone treated grains were lower than those of untreated, grain quality indicators were not affected by ozone treatment, germination of ozone treated grains was about $20 \%$ higher than untreated, baking properties were not affected by ozone treatment. The treatment of grain with ozone makes stored grain more expensive approximately 5.00 EUR per ton, due to additional technical equipment required to ensure the ozone treatment process. One can conclude from the attained results that processing the restored grain under the conditions mentioned reduces the grain microbiological contamination; it does not affect the grain quality parameters and baking properties; it slightly improves the grain germination rate and has no impact upon the shell of the grain.

Keywords - wheat storage, ozone, microbiological safety

\section{INTRODUCTION}

Technologies are becoming increasingly topical in agriculture that do not have a harmful impact upon the environment. This also applies to the traditional and conservative grain growing. Since the middle of the 20th century investigations have started of the impact of ozone upon grain - that ozone can replace weed control and grain pickling chemicals, as well as improve the quality of the grain during drying and storage [1].

\section{Online ISSN 2256-070X


The main factors that have negative impact upon the storage quality of grain are the presence of pathogens and microorganisms that can form toxins which are harmful to human and animal health [2]. Also Reed, 2006 [3] notes that grain spoilage is mainly caused by moulds. In study of Sauer et al., 1992 [4] are analyzed the effects of various mould species upon the grain. The European Commission has worked out recommendations [5] that set maximum levels for toxins produced by microorganisms in cereals and cereal products. One way to control the growth of moulds and thus reduce the formation of toxins is to regulate the temperature and moisture content of the grain through active ventilation [2]. Several authors recommend adding ozone to the active ventilation air to control development of different microorganisms producing toxins more effectively. In experiments from Avdeeva et al., 2019 [6] made under the laboratory conditions to reduce toxins, there was used an ozone dose of $370 \mathrm{~g} \mathrm{~s} / \mathrm{m}^{3}$ of air with a sample treatment time of 12 hours. In experiment of Sandhu et al., 2012 [7] with the treatment of the wheat flour and the wheat starch with the ozone gas $(1500 \mathrm{mg} / \mathrm{kg}$ at a rate of $2.5 \mathrm{~L} / \mathrm{min}$ ) for 45 minutes and 30 minutes, respectively, it was revealed that the treatment with ozone had a positive effect upon the wheat flour properties. From the analysis made by other authors [8] who have treated the wheat grain and the wheat flour with ozone one and are concluded that ozone has a great potential for the improvement of the functionality of the grain products simultaneously ensuring food safety. In his turn author [9], looking extensively at the studies of other authors, has found that the most frequently used ozone doses in the fumigation experiments are $30-50 \mathrm{ppm}$, and the treatment time is $5-3$ days, respectively. Under such conditions ozone is an effective fumigant for decreasing of mycotoxin amount, and microbial inactivation with minimal or no impact upon the grain quality. By active ventilation of initially $22.3 \%$ of wet grain to $14.0 \%$ moisture with a mixture of ozone and air at an $\mathrm{O}_{3}$ concentration of 700 ppm, in study [10] has found a reduction in microbiological contamination up to 3 times. The author [11] has studied the treatment of grain with ozone at a concentration of 8 $10 \mathrm{mg} \mathrm{m}^{3}$ of air and the duration of the treatment in the 36 hour. She has found that such a treatment considerably reduces the amount of microorganisms in the grain.

All the authors note the ability of ozone to reduce the impact of microorganisms and thus the effect of toxins upon the grain; however most studies have been performed with small amounts of grain under laboratory conditions. In our opinion the treatment of grain with the addition of ozone into air for ventilation in large-volume grain storage tanks and the effect of such treatment upon the pathogenic microorganisms during the storage of grain for several months has been insufficiently studied.

The aim of the research is to determine whether active ventilation of grain with an initial moisture content of $14 \%$ in high-volume grain storage tanks with an ozone additive of $28 \mathrm{mg}\left(\mathrm{m}^{3}\right)^{-1}$ and a long-term storage in these tanks reduces the amount of microorganisms compared to grain storing non-treated with the ozone in an identical tank.

\section{MATERIALS AND METHODS}

\section{A. Grain storage tanks and equipment}

For the experiments the wheat grain with the same humidity content were stored in two identical storage tanks. The investigations in the grain storage by using ozone were performed 2019 and 2020 after harvesting. The winter wheat yield was $6 \mathrm{t}$. and the storage time was approximately the five month. At the beginning of storage, during ventilation of the ozone produced by the generator in one tank (ozone tank - OT), was connected to the ventilation air taken from the outside, the other (reference tank - RT) was ventilated with the outdoor air. The height of the tanks was $5.6 \mathrm{~m}$; the wheat grain for the experiments was loaded up to $5.1 \mathrm{~m}$ level; the approximate grain weight (mass) in each tank was 17.4 t; the grain moisture was the first stage of about $14 \%$ and the second stage of about $11.2 \%$; the duration of ventilation before the long-term storage was 8 hours - in the ozone tank (OT) - with an ozone treatment and in the reference tank (RT) - with the outdoor air. In the centre of each tank there is a suspension for fixing the sensor system, installing the boxes with sensors after every metre. The structure and operating principles of the sensor system are described by Kleperis et al., 2019 [1].

Ozone for the experiments was produced by two generators, model OPV-100.03 (made by "ZhemchuzhinaRusi", RU), with a total capacity of $200 \mathrm{~g}$ $\mathrm{O}_{3} \mathrm{~h}^{-1}$ and the installed capacity of $2 \mathrm{~kW}$. To ensure a constant flow of ozone, both ozone generators were equipped with a filter to purify the ambient air. Ozone was fed into the fan air supply pipe. Next to each grain storage tank there were installed fans, connected to the grain discharge opening at the bottom of the grain storage tank with a polypropylene $0.35 \mathrm{~m}$ diameter pipe, the capacity of the fans being $7000 \mathrm{~m}^{3} \mathrm{~h}^{-1}$, their speed 2800 revolutions $\mathrm{min}^{-1}$ and the engine power $4.0 \mathrm{~kW}$.

In parallel with the measurements of the sensor system, the ozone concentration was periodically monitored with a hand-held instrument QL - $800-\mathrm{O}_{3}$ (Manufacturer QLOZONE, China), the measurement range of which is from 0 to $100 \mathrm{ppm}$ with a resolution of $0.01 \mathrm{ppm}$. The accuracy of the instrument is $1 \%$, which is equal to the minimum ozone concentration reading of $0.01 \mathrm{ppm}$. The ozone conversion, measured by volume in the air, is $1 \mathrm{ppm}$ of ozone $=2.14 \mathrm{mg} \mathrm{O}_{3} / \mathrm{m}^{3}$.

In parallel with the measurements of the sensor system, the grain moisture was periodically monitored with a hand tool Wile 66 (FarmComp Oy, Finland), the measurement ranges of the humidity range being $8-35 \%$ for grain, $6-$ $25 \%$ for the oil plants, the measuring accuracy $+/-0.5 \%$ for the whole grain.

\section{B. Sensor system for monitoring grain storage}

The sensor system is designed to record the air humidity in the grain internal space, the temperature and ozone concentration in five levels, and to transmit the recorded data to a computer, where these parameters can be read online or viewed remotely. 
Environment. Technology. Resources. Rezekne, Latvia Proceedings of the $13^{\text {th }}$ International Scientific and Practical Conference. Volume 3, 304-309

The sensor system (see Fig. 1) is formed of five sets of sensors in each grain storage tank (OT and RT tank), and of separate outdoor air temperature and humidity sensors, as well as the data storage and transmission modules (one module for each grain storage tank), which includes a microcontroller with memory for data storage, power supply and data transmission - the reception module E-32 with an antenna. The sensor system is connected to a computer via a USB converter, connected to it, and an E32 transceiver module with an antenna.

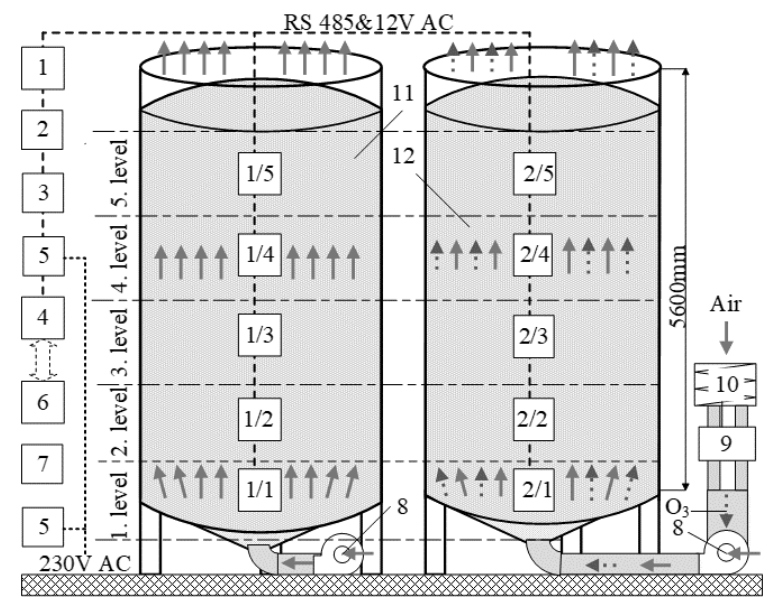

Fig. 1. A layout diagram of the grain storage equipment and sensors. 1. The outdoor humidity sensor, RH\%; 2. The outdoor temperaturesensor, $\mathrm{T}^{\circ} \mathrm{C} ; 3$. The microcontroller; 4., 6. The transceiver E32; 5. The source of power; 7. The computer interface; 8.The fan; 9. The ozone generator; 10 . Air filter; 11. The reference tank (RT); 12. The grain storage tank with the ozone supply (OT); 1/1 - 1/5 Sensors, $\mathrm{T}^{\circ} \mathrm{C}, \mathrm{RH} \%$; 2/1 - 2/5 Sensors, $\mathrm{T}^{\circ} \mathrm{C}, \mathrm{RH} \%, \mathrm{O}_{3}$, ppm.

The microcontroller and the connected sensors communicate via the RS485 communication channel with a MODBUS RTU data exchange protocol [1]. The transceiver module E-32 is used for data transfer between the controller and the computer. The E-32 series modules are UART wireless modules, based on the SEMTECH SX1276 / SX1278 RF chip, using a LoRa transmission technology for the data exchange [12].

The user program of the grain storage process monitoring system works with a database and allows to see the changes of the measurements of the selected sensors in real time or in a certain time interval (in a table and a diagram display). The user program allows one to select the measurement display of a specific parameter (humidity, temperature, the ozone concentration) in different layers of the grain storage tank in the selected time period (real time or historical data during the selected time interval).

During the harvesting season, the sensor system was used to control the active ventilation and ozone treatment process of the grain [12], but during long-term storage to periodically control the temperature and humidity of the stored grain in the inter-grain space.

\section{Analysis of the wheat grain quality}

Determination of the amount of mesophilic aerobic and anaerobic bacteria (TPC) was determined according to LVS EN 4833: 2003. For analysis of the moisture content, water activity and microbiological analysis there were used approximately 100 g ground wheat grains. All the parameters were analysed for the wheat grain samples, taken from each storage tank (without ozone and with ozone treatment).

The moisture content of the analysed wheat grain was determined according AACC Method 44-15.02, in the oven Memmert ULM 500 GmbH Memmert, Germany). The water activity was determined using the LabSwift-aw devise (AG Novasina, Switzerland).

The gluten, starch and protein content was determined using (Grain Analyzer Infratec ${ }^{\mathrm{TM}} 1241$, Denmark). For analysis there were used approximately $500 \mathrm{~g}$ of the whole wheat grain.

Wheat grain germination capacity (after 3 days) and rate (after 5 days) was determined. The 100 wheat grain was placed in the Petri dish with filterpaper, pour $4 \mathrm{ml}$ of water and place in a dark place at the room temperature $\left(22 \pm 2{ }^{\circ} \mathrm{C}\right)$.

\section{RESULTS AND DISCUSSION}

The grain storage research was performed in two stages - 22.08.2019. - 03.02.2020. and 12.08.2020 - 24.01.2021. On the first day of grain storage both tanks were ventilated for 8 hours, in the ozone tank (OT) - with an ozone supply of $28 \mathrm{mg}\left(\mathrm{m}^{3}\right)^{-1}$ in the ventilation air; in the reference tank (RT) - with the outdoor air. This was followed by storage for the indicated periods of time (approximately five months), with the sensor system periodically monitoring the storage modes. At the first and the second stages of the research the grain samples for the assessment of their biological properties and quality at the beginning and at the end of storage were taken at tank levels $1 / 1$ and $2 / 1$ (see Fig. 1).

In the studies on the use of ozone in the treatment of cereals and their products, all the authors believe that the use of ozone essentially reduces the development of microorganisms [2, 4, 6, etc.]. This thesis is also confirmed by our study. The total amount of microorganisms in the grain was already below the allowed $10 \times 5 \mathrm{CFU} \mathrm{g}^{-1}$ at the beginning of storage; in both storage periods it was considerably reduced for the ozone treated grain, as compared to the storage of the ozone nontreated grain.

The development of microorganisms is essentially influenced by the grain moisture and the water activity. The water activity reflects the activity of the free water in the food product; for dry products the water activity may be $0.4-0.6$. The summary of the water activity of the wheat grain at the beginning and the end of storage is shown in Figure 2. As the moisture content of the grain slightly changes during storage due to external conditions, this also affects the water activity of the grain. For the 
non-treated grain with the ozone the water activity increases slightly, but for the ozone treated grain it decreases; however the changes are insignificant. On the whole, one can concluded that ozone treatment does not affect ( $\mathrm{p}>0.05)$ the water activity of the wheat grain.

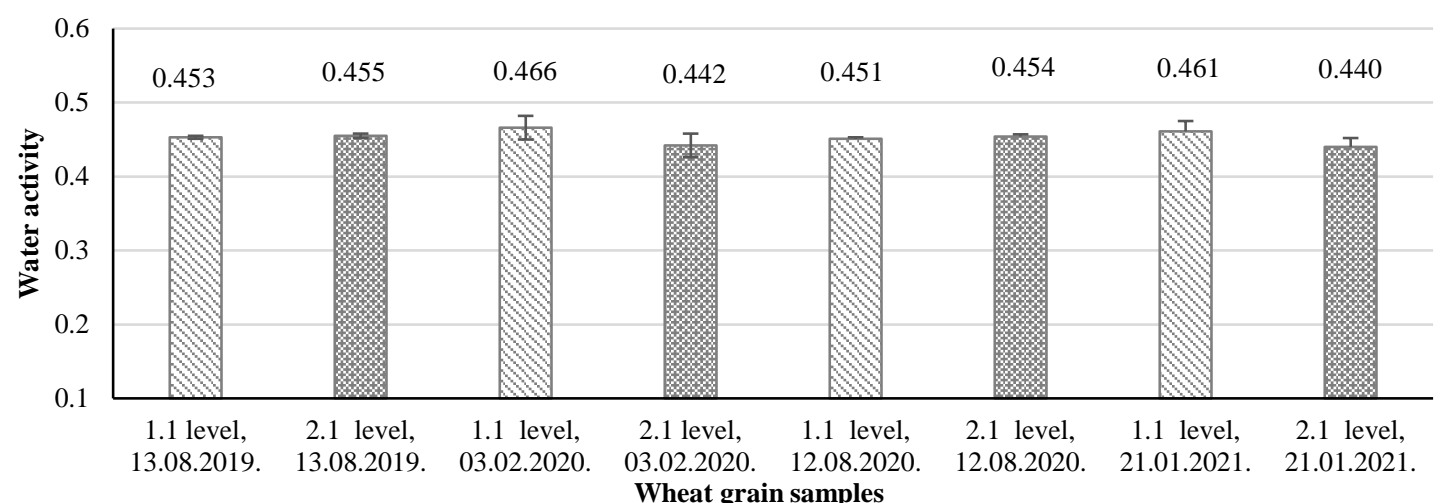

Fig. 2. The water activity of the wheat grain.

1.1 level - ozone non-treated and 2.1 level - ozone treated grain at the bottom of the tank.

In order to assess the baking properties of ozone treated wheat grain, it is important to compare the quality of the ozone treated and the ozone non-treated grain, which is characterised by the moisture of the grain, the protein the starch and the gluten content, as well as the fall figure.

In order the wheat grain to be suitable for bread baking, its moisture content is allowed up to $14 \%$, the protein content - not less than $12.5 \%$, the minimum gluten content $-28 \%$, the falling number - not less than $220 \mathrm{~s}$. The quality parameters of the stored wheat grain are summarized in Table I.

TABLE I.

\begin{tabular}{|l|c|c|c|c|c|}
\hline \multicolumn{5}{|c|}{ Quality of the grain before and after the grain storage } \\
\hline Sample No. & $\begin{array}{c}\text { Moisture, } \\
\text { \% }\end{array}$ & $\begin{array}{c}\text { Protein, } \\
\mathbf{g} \mathbf{1 0 0} \mathbf{~ g}^{-1}\end{array}$ & $\begin{array}{c}\text { Starch, g } \\
\mathbf{1 0 0} \mathbf{g}^{-1}\end{array}$ & $\begin{array}{c}\text { Gluten, } \\
\text { \% }\end{array}$ & $\begin{array}{c}\text { Falling } \\
\text { number, s }\end{array}$ \\
\hline $\begin{array}{l}\text { Level 1.1, } \\
\text { 13.08.19. }\end{array}$ & 13.9 & 16.4 & 63.6 & 35.5 & 306 \\
\hline $\begin{array}{l}\text { Level 1.1, } \\
\text { 03.02.20. }\end{array}$ & 14.2 & 16.0 & 65.2 & 35.5 & 297 \\
\hline $\begin{array}{l}\text { Level 2.1, } \\
\text { 13.08.19. }\end{array}$ & 14.0 & 16.3 & 63.9 & 36.3 & 325 \\
\hline $\begin{array}{l}\text { Level 2.1, } \\
\text { 03.02.20. }\end{array}$ & 14.4 & 16.1 & 64.4 & 35.3 & 229 \\
\hline $\begin{array}{l}\text { Level 1.1, } \\
\text { 12.08.20. }\end{array}$ & 11.2 & 16.2 & 64.8 & 35.5 & 300 \\
\hline $\begin{array}{l}\text { Level 1.1, } \\
\text { 24.01.21. }\end{array}$ & 12.8 & 16.0 & 64.4 & 35.6 & 287 \\
\hline $\begin{array}{l}\text { Level 2.1, } \\
\text { 12.08.20. }\end{array}$ & 11.1 & 16.5 & 64.7 & 36.0 & 310 \\
\hline $\begin{array}{l}\text { Level 2.1, } \\
\text { 24.01.21. }\end{array}$ & 13.0 & 16.0 & 64.6 & 36.1 & 290 \\
\hline
\end{tabular}

1.1 level -ozone non-treated and 2.1 level - ozone treated grain at the bottom of the tank.

According to the data obtained in the study (Table I), it can be concluded that ozone does not significantly affect the quality of wheat grains during storage. The falling number of wheat grain increases slightly during storage, but this is not significant changes. As no significant changes in the quality of wheat grain were found, then didn't show any significant differences in the quality of wheat bread. Therefore, it can be concluded that did not significantly affect the baking properties of the wheat grain.

Researchers have differing views on the effects of ozone on the wheat germination capacity and germination rate. Tiwari et al., 2010, [9] treating the wheat grain for 3 - 5 days with an ozone concentration of $50 \mathrm{ppm}$, have noticed a slight decrease in the germination capacity. Also [8] considers that high ozone doses and long treatments can reduce the grain germination capacity. The authors [7] believe that the ozone treatment does not affect the germination capacity. These authors have performed experiments under laboratory conditions with small amounts of grain [6], on the other hand, regard that the use of ozone treated seeds increases the yield by $10-25 \%$, although without indicating the ozone concentration. The results of the germination rate for and germination capacity analyses after long-term storage of the grain are shown in Table II.

TABLE II

\begin{tabular}{|c|c|c|}
\hline \multicolumn{3}{|c|}{$\begin{array}{c}\text { The germination rate and germination capacity of the analysed } \\
\text { grain }\end{array}$} \\
\hline \multirow[b]{2}{*}{ Sample No. } & \multicolumn{2}{|c|}{ Number of the germinated grain, \% } \\
\hline & $\begin{array}{l}\text { Germination } \\
\text { rate }\end{array}$ & $\begin{array}{l}\text { Germination } \\
\text { capacity }\end{array}$ \\
\hline Level 1.1, 13.08.2019. & 25 & 48 \\
\hline Level 1.1, 03.02.2020. & 37 & 56 \\
\hline Level 2.1, 13.08.2019. & 38 & 75 \\
\hline Level 2.1, 03.02.2020. & 77 & 97 \\
\hline Level 1.1, 30.08.2020. & 80 & 90 \\
\hline Level 1.1, 24.01.2021. & 73 & 75 \\
\hline Level 2.1,12.08.2020. & 81 & 81 \\
\hline Level 2.1, 24.01.2021. & 97 & 100 \\
\hline
\end{tabular}

1.1 level - ozone non-treated and 2.1 level - ozone treated grain at the bottom of the tank.

The results of our experiments are not convincing either. For the ozone non-treated grain (Level 1.1), at the first stage of the experiments, after about five months of storage, the germination capacity and the germination rate have increased but at the second stage they have decreased. On the other hand, for the ozone treated grain, the 
Environment. Technology. Resources. Rezekne, Latvia Proceedings of the $13^{\text {th }}$ International Scientific and Practical Conference. Volume 3, 304-309

germination capacity and the germination rate after storage have increased by about $20 \%$ at both stages of the experiments. It is possible that the results, different from other studies [8,9], can be explained by about a three times lower ozone concentration and a shorter treatment time.

To study the grain morphology, two series of research were performed under the ECLIPSE L150 optical microscope (Nikon). There were analyzed the outer appearance and the cross-sectional view of the grain obtained by an optical microscope.
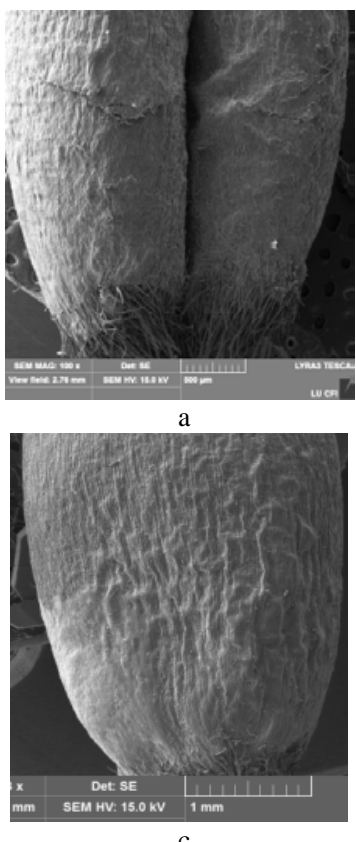

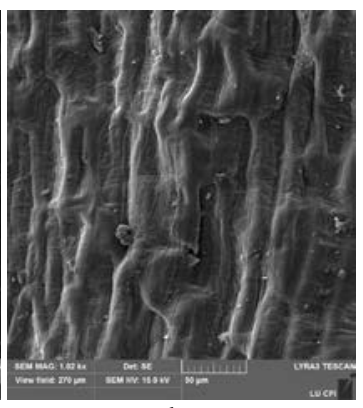

b

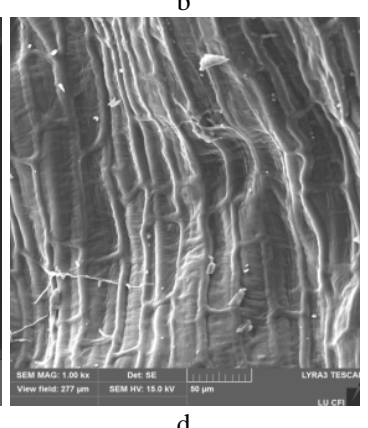

d
Fig. 3. The morphology of the wheat grain after storage

Due to the corrugated and wavy surface, an image in good magnification could be obtained during the analysis of the outer appearance of the grain [only] from separate surface areas. Figure 3 (a; b - 1.1 level, ozone non-treated and c; d - 2.1 level, ozone treated grain) shows typical examples of the four grain. One can draw a conclusion from the performed study that, within the limits of variations of the surface relief, which is characteristic for the samples, no visually detected differences between the ozone treated and the ozone non-treated grain were observed. All the four images of the grain were obtained at the same magnification. The main focus is turned at the grain seed coat. The grain seed coat is clearly visible in the samples examined; no shell peeling or other essential differences between the ozonized and ozone non-treated grain shell were observed. A similar result has been found in the study by [13].

A conclusion follows from the morphological examination of the grain that the grain stored under the impact of the ozone treatment with a concentration of 28 $\mathrm{mg}\left(\mathrm{m}^{3}\right)^{-1}$ no damage or destruction was made to the grain seed coat, ensuring at the same time the limitation of microbiological contamination.

\section{CONCLUSIONS}

The treatment of the grain, stored with ozone at a concentration of $28 \mathrm{mg}\left(\mathrm{m}^{3}\right)^{-1}$ for 8 hours, demonstrated the efficiency of ozone concerning limitation of the microbiological contamination without affecting the quality of the stored grain.

The study of the grain quality parameters and the baking properties showed that they are not essentially affected by ozone treatment under the conditions used in the study.

The germination capacity and the germination rate of the ozone treated grain at both stages of the experiments increased after storage by about $20 \%$.

As the morphological examination of the grain shows, the treatment of ozone with a concentration of $28 \mathrm{mg}\left(\mathrm{m}^{3}\right)$ 1 did not damage the grain shell, while ensuring the limitation of microbiological contamination.

The sensor systems, developed and installed in the grain storage tanks, provided an opportunity to monitor the grain storage on a computer, both on the farm and from the distance. Particularly important in the production conditions was the ability to control the temperature and humidity of the grain in the inter-grain space in the grain storage tanks in layers during grain storage.

\section{ACKNOWLEDGMENTS}

The financial support of Rural Support Service Project No 18-00-A01620-000003 "Technology development of grain drying with active ventilation using ozone" is greatly acknowledged. The authors thank Dr.sc.ing. Aivars Cesnieks and Ing. Sandris Cesnieks, representatives of the farm "Mazkalnini", Tervetes region, Tervete district, Latvia for the support and active cooperation.

\section{REFERENCES}

[1] Kleperis J., Kristins A., Veinbergs J. et .al. “Applicataion of Ozone in Grain Drying: Autonomous Sensor System Construction and Pecularities." Proceedings of the 9th International Scientific Conference Rural Development 2019, 34-39.

[2] Campabadal, Carlos A., "Ozonation Systems as a Non-Chemical Alternative for Stored Grain Protection" (2013). Open Access Dissertations. https://docs.lib.purdue.edu/open_access_dissertations/170

[3] Reed C. R. 2006. Managing Stored Grain to Preserve Quality and Value. St. Paul, MN: American Association of Cereal Chemists.

[4] Sauer D. B., Meronuck R. A., Christensen C. M. 1992. Microflora. In Storage of Cereal Grains and their Products.313-340. 4th Ed. D. B. Sauer. Ed. St. Paul, MN: American Association of Cereal Chemists.

[5] Komisijas Ieteikums2013/165/ES (2013. gada 27. marts) par T-2 un HT-2 toksīnu klātbūtni labībā un graudaugu produktos. (OV L 91, 3.4.2013., 12.-15.lpp.)) (Recommendation of the Commission of 2013/165/ES (27.03.2013) on the presence of toxins in the grain and cereal products (OV L91, 3.4.2013., pp. 12.-15.)) (In Latvian)

[6] Avdeeva, V., Zorina, E., Bezgina, J., \& Kolosova, O. (2019). Ozone effects on toxicity of wheat grain and grain mixtures. Engineering for Rural Development, 17, 764-767. https://DOI: 10.22616/ERDev2019.18.N081

[7] Sandhu, H. P. S., Manthey, F. A., \& Simsek, S. (2012). Ozone gas affects physical and chemical properties of wheat (Triticum 
aestivum L.) starch. Carbohydrate Polymers, 87(2), 1261-1268. https://doi.org/10.1016/j.carbpol.2011.09.003

[8] Zhu, F. (2018). Effect of ozone treatment on the quality of grain products. Food Chemistry, 264(May), 358-366. https://doi.org/10.1016/j.foodchem.2018.05.047

[9] Tiwari, B. K., Brennan, C. S., Curran, T., Gallagher, E., Cullen, P. J., \& Donnell, C. P. O. (2010). Application of ozone in grain processing. Journal of Cereal Science, 51(3), 248-255. https://doi.org/10.1016/j.jcs.2010.01.007

[10] Raila A., Lugauskas A., Steponavičius D., Railiené M., Steponavičienė A., Zvicevičius E. 2006. Application of ozone for reduction of mycological infection in wheat grain. Annals of Agricultural and Environmental Medicine, Vol. 13 (2), pp. 287294.

[11] Троцкая Т.П. Электроактивирование процессов сушки растительных материалов. Автореферат диссертации доктора технических наук. 32с., Москва, ГАУ, 1998. Electroactivation of drying processes of plant materials. Abstract of the dissertation of a doctor of technical sciences. 32 pages, Moscow, GAU, 1998 (In Russian).

[12] Rucins A., Viesturs D., Kristins A., Bruveris J. 2020 "Investigations in Intensification of Grain Drying by Active Ventilation Applying Ozone.” Engineering for Rural Development 19: 231-37. https://doi.org/10.22616/ERDev.2020.19.TF057.

[13] Savi G.D., Piacentini K.C., Bittencourt K.O., Scussel V.M. Ozone treatment efficiency on Fusarium graminearum and deoxynivalenol degradation and its effects on whole wheat grains (Triticum aestivum L.) quality and germination. Journal of Stored Products Research, 59 (2014), pp. 245-253. 